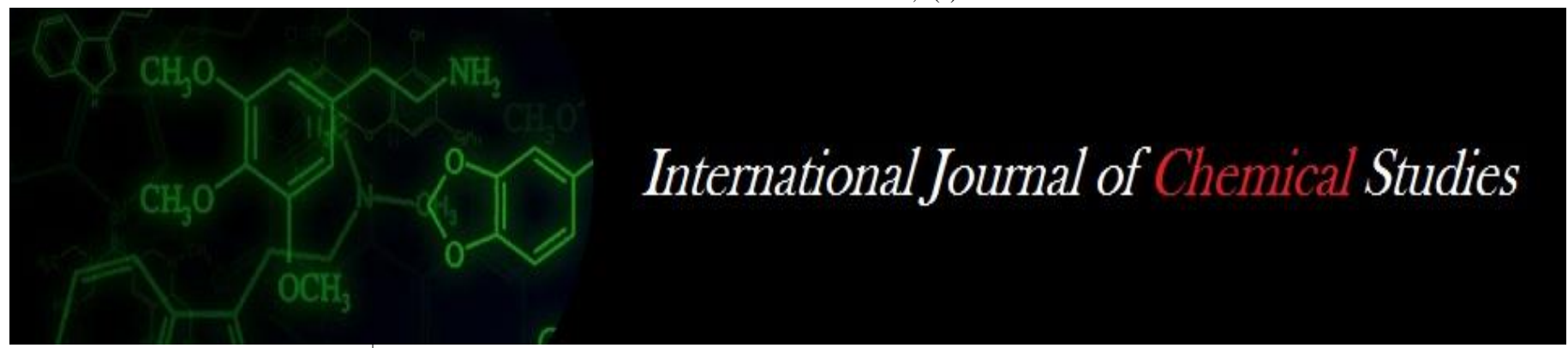

P-ISSN: 2349-8528

E-ISSN: 2321-4902

www.chemijournal.com

IJCS 2020; 8(2): 1831-1836

(C) 2020 IJCS

Received: 22-01-2020

Accepted: 24-02-2020

Anand Prasad Rakesh

K.V.K. Jale, Darbhanga, Bihar, India

Vandana Kumari

Department of Soil Science

Dr. Rajendra Prasad Central

Agricultural University, Pusa,

Samastipur, Bihar, India

Divyanshu Shekhar

K.V.K. Jale, Darbhanga, Bihar,

India

Corresponding Author:

Vandana Kumari

Department of Soil Science

Dr. Rajendra Prasad Central

Agricultural University, Pusa,

Samastipur, Bihar, India

\section{Direct and residual effect of organic manure amended sulphur on yield and nutrient uptake in mustard-rice cropping system}

\author{
Anand Prasad Rakesh, Vandana Kumari and Divyanshu Shekhar
}

DOI: https://doi.org/10.22271/chemi.2020.v8.i2ab.9027

\begin{abstract}
An experiment was conducted to evaluate the direct effect of different level of sulphur alone or in combination with organic manures on mustard and residual effect on rice crops in calcareous soil of north India. Sulphur application significantly increased the yield of mustard as well as rice, $\mathrm{S}$ concentration and its uptake by mustard (seed+stover) as well as available $-\mathrm{S}$ content in post- harvest soil samples after mustard and rice (grain+straw). The optimum level of $S$ was worked out to be $60 \mathrm{~kg} \mathrm{~S}^{-1}$ ha ${ }^{-1}$ for mustard seed and stover production. However, with regards to total $\mathrm{S}$ uptake, the optimum dose appeared at 100 $\mathrm{kg} \mathrm{S} \mathrm{ha}{ }^{-1}$. The beneficial effect of organic manure was evident in enhancing the seed and stover production, S-c oncentration in seed, S-uptake (Seed+Stover) by mustard and available-S content in postharvest soil samples from 9.8 to $10.7 \mathrm{q} \mathrm{ha}^{-1}, 37.5$ to $40.5 \mathrm{q} \mathrm{ha}^{-1}, 0.779$ to 0.821 per cent, 20.39 to $32.47 \mathrm{~kg}$ $\mathrm{ha}^{-1}$ and 25.7 to $86.5 \mathrm{mg} \mathrm{kg}^{-1}$, respectively and the grain yield, S-content in grain, straw, total S-uptake (grain + straw) and available $S$ content in post-harvest samples of rice from 47.2 to $49.8 \mathrm{q} \mathrm{ha}^{-1}, 0.088$ to 0.098 per cent, 0.123 to 0.175 per cent, 13.83 to $17.98 \mathrm{~kg} \mathrm{ha}^{-1}$ and 24.2 to $37.9 \mathrm{mg} \mathrm{kg}^{-1}$, respectively. Among the organic manures, biogas slurry (BGS) proved to be better source in enhancing seed yield, stover/straw yield, S-uptake, and available-S in post-harvest soil samples after mustard and rice. The residual effect of higher level of $S$ along with BGS proved more effective with respect to $S$ nutrition to rice.
\end{abstract}

Keywords: Organic manures, mustard, residual effect, rice, sulphur

\section{Introduction}

Modernisation of agriculture involving high input and output activity necessitated the importance of sulphur, and now-a-days sulphur is called as the fourth major plant nutrient as most crops absorb sulphur in quantity equivalent to phosphorus. However, with the increased use of high analysis S-free fertilizers, lower use of organic manure and very low rate of application or practically no application of sulphur fertilizers, the reserves of sulphur in soil have started depleting and are limiting the soil productivity (Kour et al; 2007) ${ }^{[8]}$. Sulphur is best known for its role in balanced fertilization and consequently in crop production. It is essential nutrient for the formation of amino acid, synthesis of chlorophyll, oil in oilseeds and improvement in the nutritive quality of forage and fodder crops. Sulphur application increases the yield of mustard by 12 to $48 \%$ under irrigated and 17 to $24 \%$ under rainfed conditions (Aulakh and Pasricha; 1988) ${ }^{[2]}$. Pyrite, Pressmud and FYM application either alone or in combination significantly increased the lentil yield (Sinha and Sakal; 1993a) ${ }^{[14]}$. Increasing level of S increased S content of both grain and stover significantly over control. Sulphur content increased from 0.415 to 0.499 per cent in grain, 0.150 to 0.241 per cent in straw and consequently its uptake increased from 5.34 to $7.42 \mathrm{~kg} \mathrm{ha}^{-1}$ with the application of $45 \mathrm{~kg} \mathrm{~S} \mathrm{ha-}$ 1 . Generally, sulphur application benefits more than one crop grown on sequence and produces a significant residual response. It was estimated that depending up on the systems, the directly fertilized crop contributed $33-82 \%$ to the rotational response and the crop raised to test the residual value, contributed $18-67 \%$ (Tandon, 1991) ${ }^{[18]}$. The residual effect of pyrites and organic manures (FYM and Pressmud) were evaluated with respect to $\mathrm{S}$ nutrition of crops in a field experiment on sandy loam calcareous soil (Sinha and Sakal; 1993b) ${ }^{[15]}$. 
Keeping in view the limited information available, the experiment was conducted to evaluate the effect of $\mathrm{S}$ nutrition on mustard and its residual effect on subsequent rice in calcareous soil of north Bihar.

\section{Materials and Methods}

A field experiment was conducted on calcareous soil under mustard-rice cropping system in the nursery Jhilley of Pusa farm, Bihar which was found deficient in available sulphur. Before sowing a composite sample was taken and was analysed for their general properties following standard methods. Soil $\mathrm{pH}$ was determined in a soil suspension in water with soil and water ratio of 1:2 by using glass electrode pH meter (Jackson,1978) ${ }^{[6]}$ and electrical conductivity was determined with the help of conductivity bridge (Jackson, 1978) ${ }^{[6]}$. Organic carbon was was estimated by the wet digestion method as given by Walkley and Black (1934) ${ }^{[20]}$. Determination of micronutrients like $\mathrm{Zn}, \mathrm{Fe}, \mathrm{Cu}$ and $\mathrm{Mn}$ was done with the help of atomic absorption spectrophotometer in DTPA extract as suggested by Lindsay and Norvell (1978) ${ }^{[9]}$. Available sulphur was determined by turbidimetric method as given by Chesnine and Yien (1951) ${ }^{[4]}$. The experimental site was sandy loam in texture, slightly alkaline in reaction, low in organic carbon, available $\mathrm{N}, \mathrm{P}, \mathrm{K}$ and $\mathrm{S}$ (Table 1). The treatment consisted of seven level of sulphur $(0,20,40,60$, 80,100 and $120 \mathrm{~kg} \mathrm{~S} \mathrm{ha}^{-1}$ ) alone or along with organic manures and were replicated thrice in randomised block design. Source of S-Phosphogypsum (1\% $\mathrm{P}_{2} \mathrm{O}_{5}$ and $\left.14 \% \mathrm{~S}\right)$, Source of organic manure-FYM/ Biogas slurry $\left(5.0 \mathrm{t} \mathrm{ha}^{-1}\right)$. Two test crops Mustard (var. Varuna) and rice (var. Rajshree) were grown successively to see the direct and residual effect of sulphur alone or along with organic manure.

The required quantity of two source of organic manure i.e FYM and Biogas slurry (BGS) were amended with different level of sulphur and incubated for one month before application in mustard (Table 2 and Table 3). The recommended dose of $80 \mathrm{~kg} \mathrm{~N}, 40 \mathrm{~kg} \mathrm{P}_{2} \mathrm{O}_{5}$ and $40 \mathrm{~kg} \mathrm{~K}_{2} \mathrm{O}^{-} \mathrm{ha}^{-}$ ${ }^{1}$ in mustard and $100 \mathrm{~kg} \mathrm{~N}, 60 \mathrm{Kg} \mathrm{P}_{2} \mathrm{O}_{5}$ and $40 \mathrm{~kg} \mathrm{~K}_{2} \mathrm{O} \mathrm{ha}^{-1}$ in rice as urea, DAP and Murate of Potash, respectively were added. Since the plot was deficient in available $\mathrm{Zn}$, a basal application of $10 \mathrm{~kg} \mathrm{Zn}$ as Zinc oxide was done uniformly to all plots. Both the test crops were grown till maturity to records yield. Grain and stover/straw samples of both crops were taken from each plot for their chemical analysis. Postharvest soil samples were also taken after both crops for different studies. Plant samples were collected and dried in the oven at $65 \pm 1{ }^{\circ} \mathrm{C}$ and ground in Willey mill fitted with stainless steel blades. The samples were digested in binary acid mixture of nitric and perchloric acid for extraction of total sulphur content as per the method of Tabatabai (1982) [16]. Sulphur in the extract was determined by turbidimetric method given by Chesnine and Yien (1951) ${ }^{[4]}$.

Table 1: General properties of initial surface soil of experimental plot

\begin{tabular}{|c|c|c|}
\hline S. No. & Soil properties & Content \\
\hline \multirow{3}{*}{1.} & Sand $(\%)$ & 76.0 \\
\cline { 2 - 3 } & Silt $(\%)$ & 12.0 \\
\cline { 2 - 3 } & Clay (\%) & 12.0 \\
\cline { 2 - 3 } & Textural class & Sandy loam \\
\hline 2. & $\mathrm{pH}(1: 2)$ & 8.4 \\
\hline 3. & $\mathrm{EC}\left(\mathrm{dSm}^{-1}\right)$ & 0.35 \\
\hline 4. & Organic carbon $\left(\mathrm{g} \mathrm{kg}^{-1}\right)$ & 4.10 \\
\hline 5. & Free CaCO $\left(\mathrm{g} \mathrm{kg}^{-1}\right)$ & 334 \\
\hline 6. & $\mathrm{CEC}\left[{\left.\mathrm{Cmol}\left(\mathrm{P}^{+}\right) \mathrm{kg}^{-1}\right]}\right.$ & 8.80 \\
\hline \multirow{3}{*}{7.} & Available N $\left(\mathrm{kg} \mathrm{ha}^{-1}\right)$ & 240 \\
\cline { 2 - 3 } & $\mathrm{P}_{2} \mathrm{O}_{5}\left(\mathrm{~kg} \mathrm{ha}^{-1}\right)$ & 14 \\
\cline { 2 - 3 } & $\mathrm{K}_{2} \mathrm{O}\left(\mathrm{kg} \mathrm{ha}^{-1}\right)$ & 78 \\
\hline 8. & Available Zn $\left(\mathrm{mg} \mathrm{kg}^{-1}\right)$ & 0.57 \\
\hline 9. & Available Fe $\left(\mathrm{mg} \mathrm{kg}^{-1}\right)$ & 20.55 \\
\hline 10. & Available Cu $\left(\mathrm{mg} \mathrm{kg}^{-1}\right)$ & 3.62 \\
\hline 11. & Available Mn $\left(\mathrm{mg} \mathrm{kg}^{-1}\right)$ & 9.92 \\
\hline 12. & Total S & 349.8 \\
\hline 13. & Available S & 8.26 \\
\hline
\end{tabular}

Table 2: Chemical composition of untreated organic manures used in the experiment before incubation

\begin{tabular}{|c|c|c|}
\hline Parameters & FYM & BGS \\
\hline Organic C $\left(\mathrm{g} \mathrm{kg}^{-1}\right)$ & 353 & 452 \\
\hline Total N (\%) & 0.84 & 1.29 \\
\hline $\mathrm{P}(\%)$ & 0.75 & 0.93 \\
\hline $\mathrm{K}(\%)$ & 0.69 & 1.12 \\
\hline $\mathrm{S}(\%)$ & 0.63 & 0.82 \\
\hline $\mathrm{Zn}\left(\mathrm{mg} \mathrm{kg}^{-1}\right)$ & 79 & 102 \\
\hline $\mathrm{Fe}\left(\mathrm{mg} \mathrm{kg}^{-1}\right)$ & 2421 & 2508 \\
\hline $\mathrm{Cu}\left(\mathrm{mg} \mathrm{kg}^{-1}\right)$ & 39 & 50 \\
\hline $\mathrm{Mn}\left(\mathrm{mg} \mathrm{kg}^{-1}\right)$ & 172 & 228 \\
\hline
\end{tabular}

Table 3: $\mathrm{CaCl}_{2}$ extractable sulphur in incubated organic matter at the time of application

\begin{tabular}{|c|c|c|c|c|}
\hline S levels & \multicolumn{2}{|c|}{ FYM } & \multicolumn{2}{c|}{ BGS } \\
\hline & Sconc $_{\text {(\%) }}$ & Amount of S added $\left(\mathbf{k g ~ h a}^{-1}\right)$ & S $_{\text {conc }}(\%)$ & Amount of S added (kg ha \\
\end{tabular}

N.B. Dose of organic manure application $=50 \mathrm{q} \mathrm{ha}^{-1}$

\section{Results and Discussion}

\section{Direct effect of Sulphur on mustard crop}

Seed and stover yield of mustard as influenced by different levels of sulphur application alone or along with organic manure varied from 8.3 to 12.7 and 33.7 to $44.2 \mathrm{q} \mathrm{ha}^{-1}$ in different treatments (Table 4). Seed and stover yields were significantly increased with increasing $\mathrm{S}$ levels up to $60 \mathrm{~kg} \mathrm{~S}$ $\mathrm{ha}^{-1}$ beyond which there was sharp decline in yield. The highest seed and stover yields were found to be 11.6 and 42.6 $\mathrm{q} \mathrm{ha} \mathrm{h}^{-1}$, respectively at $60 \mathrm{~kg} \mathrm{ha}^{-1}$. The increase in mustard yield due to sulphur application were also reported by Sakal et al. (1996) ${ }^{[11]}$ in Bihar soils and Kour et al (2014) ${ }^{[7]}$ in subtropical Inceptisol of Jammu, North India. The response data were fitted significantly in to quadratic equations which were as below; 
Seed yield (without O.M) $=8.38+0.55 \mathrm{X}-0.00037 \mathrm{X}^{2}\left(\mathrm{R}^{2}\right.$ $\left.=0.881^{* *}\right)$

$\mathrm{X}_{\text {max. }}=62.3 \mathrm{~kg} \mathrm{~S} \mathrm{ha}^{-1}, \mathrm{Y}_{\max } .=10.97 \mathrm{q} \mathrm{ha}^{-1}$

Seed yield (with FYM) $=9.15+0.059 \mathrm{X}-0.00047 \mathrm{X}^{2}\left(\mathrm{R}^{2}\right.$ $=0.872 * *)$

$\mathrm{X}_{\max }=62.3 \mathrm{~kg} \mathrm{~S} \mathrm{ha}^{-1}, \mathrm{Y}_{\max .}=10.97 \mathrm{q} \mathrm{ha}^{-1}$

Seed yield $($ with $B G S)=9.63+0.066 \mathrm{X}-0.00056 \mathrm{X}^{2}\left(\mathrm{R}^{2}\right.$ $=0.686 * *)$

$\mathrm{X}_{\text {max. }}=59.5 \mathrm{~kg} \mathrm{~S} \mathrm{ha}^{-1}, \mathrm{Y}_{\max .}=11.60 \mathrm{q} \mathrm{ha}^{-1}$

Mean seed yield $=9.06+0.061 X-0.00047 X^{2}\left(R^{2}=0.823\right.$ $* *)$

$X_{\max .}=64.8 \mathrm{~kg} \mathrm{~S} h a^{-1}, \mathrm{Y}_{\max }=11.02 \mathrm{q} \mathrm{ha}^{-1}$

Table 4: Direct effect of sulphur application alone or along with organic manure on yield $\left(\mathrm{q} \mathrm{ha}^{-1}\right)$ of mustard

\begin{tabular}{|c|c|c|c|c|c|c|c|c|}
\hline \multirow{3}{*}{\begin{tabular}{|c|} 
Sulphur \\
levels \\
$\left(\mathrm{kg}^{-1}\right.$ \\
ha $\left.^{-1}\right)$
\end{tabular}} & \multirow{2}{*}{\multicolumn{4}{|c|}{ Seed yield }} & \multirow{2}{*}{\multicolumn{4}{|c|}{$\begin{array}{c}\text { Straw yield } \\
\text { Organic manures }\end{array}$}} \\
\hline & & & & Organic manures & & & & \\
\hline & Control & FYM & BGS & Mean & $\begin{array}{l}\text { Or } \\
\text { rol }\end{array}$ & FYM & BGS & Mean \\
\hline 0 & 8.3 & 9.0 & 9.7 & 9.0 & 33.7 & 36.5 & 38.7 & 36.3 \\
\hline 20 & 9.5 & 10.3 & 10.7 & 10.2 & .2 & 8.2 & 39.8 & 37.7 \\
\hline 40 & 7 & 10.7 & 10.8 & 10. & 39.0 & 39.5 & 41.5 & 40.0 \\
\hline 60 & 10.8 & 11.2 & 12.7 & 11.6 & 41.5 & 42.2 & 44.2 & 42.6 \\
\hline 80 & 10.2 & 10.8 & \begin{tabular}{|l|}
11.0 \\
\end{tabular} & 10 & 38 & 38.2 & 41.0 & 39.2 \\
\hline 100 & 10. & 9.8 & 10.3 & 10. & 37 & 37.8 & 40.0 & 38.5 \\
\hline 120 & 9.8 & 9.7 & 9.8 & 9.8 & 36.7 & 36.3 & 38.5 & 37.2 \\
\hline Mean & 9.8 & 10.2 & 10.7 & & 37.5 & 38.4 & 40.0 & \\
\hline \multicolumn{3}{|c|}{ urces } & S.Emt & \multicolumn{2}{|c|}{$\begin{array}{c}\mathrm{CD} \\
(\mathrm{P}=0.05)\end{array}$} & S.Em \pm & & $\begin{array}{c}\text { CD } \\
P=0.05)\end{array}$ \\
\hline \multicolumn{3}{|c|}{ Organic manures } & 0.1 & \multicolumn{2}{|c|}{0.4} & 0.3 & & 0.8 \\
\hline \multicolumn{2}{|c|}{ S levels } & & 0.2 & \multicolumn{2}{|c|}{0.6} & 0.4 & & 1.3 \\
\hline \multicolumn{2}{|c|}{ Interactions } & & 0.4 & & - & 0.8 & & - \\
\hline
\end{tabular}

The optimum sulphur level whether it was applied alone or along with organic manure for mustard seed production as obtained from quadratic equation was $64.8 \mathrm{~kg} \mathrm{~S} \mathrm{ha}^{-1}$. The optimum rate of S application as reported by Ankineedu et al. (1985) ${ }^{[1]}$ and Tandon (1990) ${ }^{[17]}$ was 30 and $75 \mathrm{~kg} \mathrm{~S} \mathrm{ha}^{-1}$, respectively for mustard crop. The difference in optimum rate might be due to differences in soil characters as well as variety of the crop. The beneficial effect of organic manure was evident in enhancing seed and stover yield from 9.8 to 10.7 and 37.5 to $40.5 \mathrm{q} \mathrm{ha}^{-1}$, respectively. However, BGS was found superior to FYM in increasing the seed and stover yield of mustard. The superiority of BGS over FYM might be due to more sulphur content in BGS than FYM and was well decomposed. Similarly, Sinha and Sakal (1993a) ${ }^{[14]}$ found that efficiency of pyrite was remarkably enhanced when applied in combination with FYM and inferred that pyrite should be applied in combination with FYM for maximum yield of lentil in sulphur deficient soil.

\section{Sulphur concentration and uptake}

Sulphur concentration in seed varied from 0.705 to 0.906 per cent and in stover it ranged from 0.364 to 0.670 per cent (Table 5). The higher concentration of $\mathrm{S}$ in seeds as compared to stover of mustard gave support to findings of Aulakh et al. (1988) ${ }^{[2]}$. The concentration of sulphur in seed and stover increased significantly with increase in the levels of $\mathrm{S}$ over control with highest sulphur concentration at $120 \mathrm{~kg} \mathrm{~S} \mathrm{ha}^{-1}$. The increase in $\mathrm{S}$ concentration due to $\mathrm{S}$ application in soil has also been reported by Tripathi et al. (1997) ${ }^{[19]}$. FYM was found significantly superior to BGS in increasing $S$ concentration in mustard seed although their effect was at par in case of stover. The result confirms the findings of Sinha and Sakal (1993a) ${ }^{[14]}$, who observed increase in $\mathrm{S}$ concentration by the addition of organic manure. Organic manure might have immobilized soluble $S$ and reduced the leaching loss. Organic sulphur on mineralization with lapses of time was made available to crop. Data on $S$ uptake revealed that akin to yield and $\mathrm{S}$ concentration, $\mathrm{S}$ application also increased $S$ uptake by mustard (Table 6). Sulphur uptake by seed and stover varied from 5.88 to 10.29 and 12.27 to 25.78 $\mathrm{kg} \mathrm{ha}^{-1}$, respectively. Sulphur uptake by mustard was lower when $\mathrm{S}$ was applied alone through inorganic fertilizer (Phosphogypsum) as compared to those of $\mathrm{S}$ application in conjoint with organic manure. Total sulphur uptake by mustard crop ranged between 18.15 to $34.44 \mathrm{~kg} \mathrm{ha}^{-1}$ (Table 6). Increasing levels of $S$ significantly increased $S$ uptake by seed up to $60 \mathrm{~kg} \mathrm{~S} \mathrm{ha}^{-1}$, the same by stover up to $120 \mathrm{~kg} \mathrm{~S}^{-}$ 1. These results are in accordance with the findings of Sakal et al. (1996) [11] and Mishra (2001) [10] who also reported increase in sulphur uptake due to sulphur application. Increase in $S$ uptake seems to be associated with increased $S$ availability from applied $S$ with a concomitant increase in $S$ concentration and dry matter production. Among sources of organic manure BGS performed well as compared to FYM in increasing sulphur uptake by seed and stover of mustard. Both BGS and FYM were significantly superior to control in boosting sulphur uptake by seed, stover and total sulphur uptake. Similar observations were also recorded by Sinha and Sakal (1993a) ${ }^{[14]}$.

Table 5: Direct effect of sulphur application alone or along with organic manure on sulphur concentration (\%) in mustard

\begin{tabular}{|c|c|c|c|c|c|c|c|c|}
\hline \multirow{3}{*}{$\begin{array}{c}\text { Sulphur } \\
\text { levels } \\
\left(\mathrm{kg} \mathrm{ha}^{-1}\right)\end{array}$} & \multirow{2}{*}{\multicolumn{4}{|c|}{$\begin{array}{c}\text { S concentration in seed } \\
\text { Organic manures }\end{array}$}} & \multicolumn{4}{|c|}{$S$ concentration in stover } \\
\hline & & & & & \multicolumn{4}{|c|}{ Organic manures } \\
\hline & \multicolumn{3}{|l|}{ Control } & Mean & Control & FYM & BGS & Mean \\
\hline 0 & 0.705 & 0.771 & 0.766 & 0.747 & 0.364 & 0.364 & 0.401 & 0.377 \\
\hline 20 & 0.735 & 0.837 & 0.780 & 0.784 & 0.387 & 0.476 & 0.478 & 0.447 \\
\hline 40 & 0.769 & 0.842 & 0.817 & 0.809 & 0.477 & 0.558 & 0.478 & 0.504 \\
\hline 60 & 0.794 & 0.861 & 0.813 & 0.823 & 0.522 & 0.573 & 0.509 & 0.534 \\
\hline 80 & 0.800 & 0.859 & 0.836 & 0.832 & 0.571 & 0.579 & 0.530 & 0.560 \\
\hline 100 & 0.814 & 0.870 & 0.852 & 0.845 & 0.594 & 0.581 & 0.610 & 0.595 \\
\hline 120 & 0.839 & 0.906 & 0.880 & 0.875 & 0.622 & 0.637 & 0.670 & 0.643 \\
\hline Mean & 0.779 & \begin{tabular}{|l|}
0.849 \\
\end{tabular} & 0.821 & & 0.505 & 0.538 & 0.525 & \\
\hline \multicolumn{3}{|c|}{ Sources } & \multicolumn{2}{|l|}{ S.E $E_{m} \underline{\underline{H}}$} & $=0.05)$ & \multicolumn{2}{|l|}{ S.E $E_{m} \pm$} & $\mathrm{CD}(\mathrm{P}=0.05)$ \\
\hline \multicolumn{2}{|c|}{ Organic manures } & & \multicolumn{2}{|l|}{0.005} & & \multicolumn{2}{|l|}{0.006} & 0.017 \\
\hline \multicolumn{2}{|c|}{ S levels } & & \multicolumn{2}{|l|}{0.008} & & \multicolumn{2}{|l|}{0.009} & 0.027 \\
\hline \multicolumn{2}{|c|}{ Interactions } & & \multicolumn{2}{|l|}{0.014} & & \multicolumn{2}{|l|}{0.016} & 0.046 \\
\hline
\end{tabular}


Table 6: Direct effect of sulphur application alone or along with organic manure on sulphur uptake $\left(\mathrm{kg} \mathrm{ha}^{-1}\right)$ by mustard

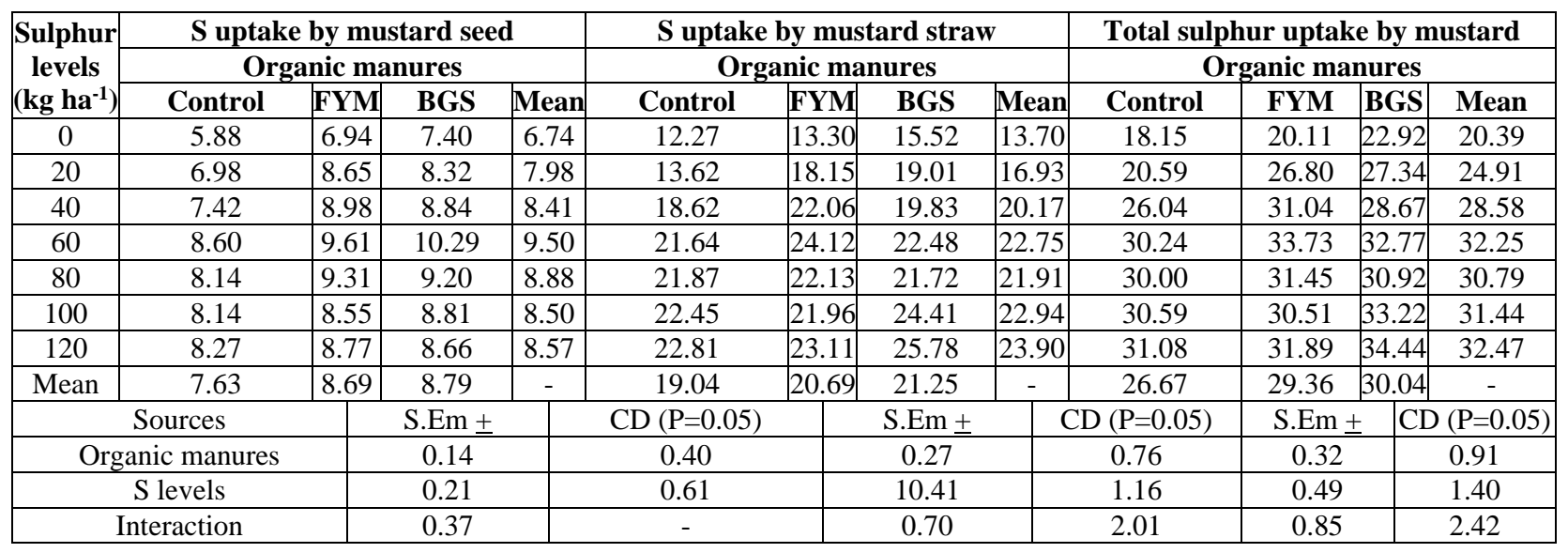

\section{Available sulphur in post- harvest soil}

The changes in available sulphur and organic carbon content due to application of different levels of sulphur alone or along with organic manure in post- harvest soil of mustard showed that sulphur applied either alone or in combination with organic manure significantly increased soil available sulphur from 18.1 to $91.2 \mathrm{mg} \mathrm{kg}^{-1}$ (Table 7). BGS performed superior over FYM in increasing available sulphur content at all level of sulphur application. Build-up in available sulphur was noted to be 353.0 per cent when applied without organic manure, whereas it increased by 377.3 and 403.9 per cent when applied with FYM and BGS, respectively. Increase in the availability of sulphur in soil with increasing level of $S$ application alone or in combination with organic manure has also been reported by Sinha and Sakal (1993a) ${ }^{[14]}$. Increased availability of sulphur in soil due to organic manure might be attributed to the mineralization of organic sulphur as well as holding water soluble $\mathrm{S}$ to minimise leaching loss.

Table 7: Available sulphur ( $\mathrm{mg} \mathrm{kg}^{-1}$ ) and organic carbon content (g $\mathrm{kg}^{-1}$ ) in post- harvest surface soil of mustard

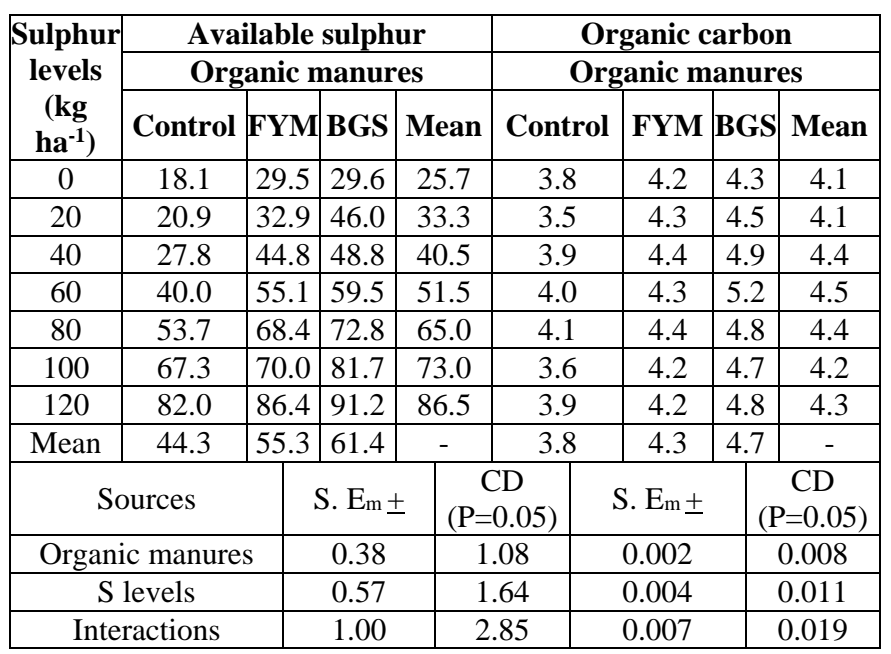

Biogas slurry was significantly superior in this respect owing to differences in its $S$ content and level of decomposition. The higher value of available-S in control treatment than initial value suggested upward movement of $\mathrm{SO}_{4}-\mathrm{S}$ during summer, the harvesting time of mustard. Organic carbon content varied from 3.5 to $5.2 \mathrm{~g} \mathrm{~kg}^{-1}$ with application of sulphur alone or along with organic manure. Organic manure was found to enhance the level of organic carbon in the soil 7significantly where BGS was more effective than FYM.

\section{Residual effect of sulphur on rice}

Sulphur research during recent years indicated that sulphur leaves its residual effect on succeeding crop, hence deserves equal attention as direct one. The recent researches also indicated that wherever the direct response was relatively lower, the succeeding crop benefited more from the residual $\mathrm{S}$. Keeping this idea in view, the residual effect of $\mathrm{S}$ was studied on rice.

\section{Grain and straw yield}

The grain and straw yield of rice varied from 41.8 to 52.3 and 66.0 to $85.3 \mathrm{q} \mathrm{ha}^{-1}$, respectively due to residual effect of sulphur alone or along with organic manure (Table 8 ). The residual value of sulphur increased the grain and straw yield from 44.1 to 51.0 and 66.7 to $82.3 \mathrm{q} \mathrm{ha}^{-1}$, respectively at 80 and $100 \mathrm{~kg} \mathrm{~S}^{-1}$ levels, respectively. However, the residual effect of lowest level of sulphur $\left(20 \mathrm{~kg} \mathrm{ha}^{-1}\right)$ was nonsignificant. The results are in accordance with the findings of Singh et al. (1991) ${ }^{[12]}$ and Sinha and Sakal (1993b) ${ }^{[15]}$ who found more pronounced residual effect at higher level of pyrite application. A crop usually takes up only a small fraction of fertilizer applied to the soil and very often a remarkable residual effect is observed in succeeding crop (Aulakh et al; 1977) ${ }^{[3]}$. The significant effect of S level was recorded up to $60 \mathrm{~kg} \mathrm{ha}^{-1}$ in case of grain. However, the residual effect up to $80 \mathrm{~kg} \mathrm{~S}^{-1}$ was found significant in case of rice straw. The residual effect of BGS was found significant in increasing the grain yield of rice from 47.2 to $49.8 \mathrm{q} \mathrm{ha}^{-1}$. This might be due to differences in their $\mathrm{S}$ content and production of organic acid on decomposition to make complexes.

Table 8: Residual effect of sulphur application alone or along with organic manure on yield $\left(\mathrm{q} \mathrm{ha}^{-1}\right)$ of rice

\begin{tabular}{|c|c|c|c|c|c|c|c|c|}
\hline \multirow{3}{*}{\begin{tabular}{|c|} 
Sulphur \\
levels \\
$(\mathrm{kg}$ \\
$\left.\mathrm{ha}^{-1}\right)$
\end{tabular}} & \multirow{2}{*}{\multicolumn{4}{|c|}{$\begin{array}{c}\text { Grain yield } \\
\text { Organic manures }\end{array}$}} & \multicolumn{4}{|c|}{ Straw yield } \\
\hline & & & & & \multicolumn{4}{|c|}{ Organic manures } \\
\hline & Control & FYM & BGS & Mean & Control & FYM & BGS & Mean \\
\hline 0 & 41.8 & 42.7 & 47.7 & 44.1 & 66.0 & 67.2 & 70.0 & 67.7 \\
\hline 20 & 45.2 & 44.5 & 48.0 & 45.9 & 74.8 & 72.0 & 72.3 & 73.0 \\
\hline 40 & 45.5 & 47.3 & 49.0 & 47.3 & 76.8 & 75.5 & 72.7 & 75.0 \\
\hline 60 & 50.8 & 51.7 & 49.3 & 50.6 & 79.0 & 76.5 & 74.0 & 76.5 \\
\hline 80 & 50.3 & 50.5 & 52.3 & 51.0 & 79.8 & 81.8 & 77.8 & 79.8 \\
\hline 100 & 48.8 & 50.5 & 52.0 & 50.4 & 83.5 & 85.3 & 78.0 & 82.3 \\
\hline 120 & 48.2 & 48.2 & 50.2 & 48.9 & 79.8 & 83.2 & 78.0 & 80.3 \\
\hline Mean & 47.2 & 47.9 & 49.8 & - & 77.1 & 77.4 & 74.7 & - \\
\hline \multicolumn{3}{|c|}{ Sources } & S.E $E_{m} \pm$ & \multicolumn{2}{|c|}{$\begin{array}{c}\mathrm{CD} \\
(\mathrm{P}=0.05)\end{array}$} & S.E $E_{m} \pm$ & \multicolumn{2}{|r|}{$\begin{array}{c}\mathrm{CD} \\
(\mathrm{P}=0.05)\end{array}$} \\
\hline \multicolumn{3}{|c|}{ Organic manures } & 0.5 & \multicolumn{2}{|c|}{1.3} & 0.8 & & - \\
\hline \multicolumn{3}{|c|}{ S levels } & 0.7 & \multicolumn{2}{|c|}{2.1} & 1.0 & & 2.9 \\
\hline \multicolumn{2}{|c|}{ Interactions } & & 1.2 & \multicolumn{2}{|c|}{ 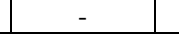 } & 1.8 & & - \\
\hline
\end{tabular}




\section{Sulphur concentration and uptake}

The concentration of sulphur increased in rice grain with increasing level of sulphur added to the first crop of mustard (Table 9). Sulphur content showed variations from 0.070 to 0.112 per cent in grain and 0.098 to 0.213 per cent in straw due to residual effect of sulphur. The effect of sulphur on sulphur content in rice grain was found non-significant at lower dose of sulphur application, however, the significant effect was observed at higher dose of sulphur application. Sulphur content in rice straw increased significantly at all the levels of sulphur application. The effect of organic manures was highly significant in enhancing the $\mathrm{S}$ content in rice grain and straw. The superiority of BGS was observed in increasing the sulphur content in rice straw, where it increased the mean sulphur content from 0.123 per cent to 0.175 per cent. The interaction effect of organic manure and sulphur level was found significant in rice grain. Higher levels of sulphur in combination with organic manure proved very effective with respect to sulphur nutrition to rice supporting the earlier observations of Sinha and Sakal (1993b) ${ }^{[15]}$ in groundnut and wheat in calcareous soil of north Bihar.

Table 9: Residual effect of sulphur application alone or along with organic manure on sulphur concentration (\%) in rice

\begin{tabular}{|c|c|c|c|c|c|c|c|c|}
\hline \multirow{3}{*}{$\left.\begin{array}{c}\text { Sulphur } \\
\text { levels } \\
\left(\text { kg ha }^{-1}\right)\end{array}\right)$} & \multicolumn{4}{|c|}{ S concentration in rice grain } & \multicolumn{4}{|c|}{$S$ concentration in rice straw } \\
\hline & \multicolumn{4}{|c|}{ Organic manures } & \multicolumn{4}{|c|}{ Organic manures } \\
\hline & Control & FYM & BGS & Mean & Control & FYM & BGS & Mean \\
\hline 0 & 0.070 & 0.082 & 0.093 & 0.082 & 0.098 & 0.100 & 0.130 & 0.109 \\
\hline 20 & 0.071 & 0.087 & 0.094 & 0.084 & 0.100 & 0.120 & 0.163 & 0.128 \\
\hline 40 & 0.084 & 0.091 & 0.096 & 0.090 & 0.117 & 0.140 & $0.167 \mid$ & 0141 \\
\hline 60 & 0.095 & 0.098 & 0.096 & 0.096 & 0.123 & 0.147 & 0.173 & 0.148 \\
\hline 80 & 0.095 & 0.104 & 0.098 & 0.099 & 0.123 & 0.150 & 0.180 & 0.151 \\
\hline 100 & 0.094 & 0.112 & 0.100 & 0.102 & 0.143 & 0.157 & 0.200 & 0.167 \\
\hline 120 & 0.107 & 0.112 & 0.101 & 0.107 & 0.160 & 0.173 & 0.213 & 0.182 \\
\hline Mean & 0.088 & 0.098 & 0.097 & - & 0.123 & 0.141 & 0.175 & - \\
\hline \multicolumn{2}{|c|}{ Sources } & & S. $E_{m} \pm$ & \multicolumn{2}{|c|}{$\mathrm{CD}(\mathrm{P}=0.05)$} & S. $E_{m} \pm$ & \multicolumn{2}{|c|}{$\quad \mathrm{CD}(\mathrm{P}=0.05)$} \\
\hline \multicolumn{2}{|c|}{ Organic manures } & & 0.002 & \multicolumn{2}{|c|}{0.005} & 0.003 & & 0.010 \\
\hline \multicolumn{2}{|c|}{ S levels } & & 0.002 & \multicolumn{2}{|c|}{0.007} & 0.005 & & 0.015 \\
\hline \multicolumn{2}{|c|}{ Interactions } & & 0.004 & \multicolumn{2}{|c|}{0.012} & 0.009 & & - \\
\hline
\end{tabular}

Sulphur uptake by rice grain, straw and total $\mathrm{S}$ uptake ranged from 2.92 to $5.64,6.48$ to 16.68 and 9.40 to $21.72 \mathrm{~kg} \mathrm{ha}^{-1}$, respectively due to residual effect of different levels of sulphur applied alone or along with organic manures (Table 10). Organic manures significantly increased the uptake of $S$ by by rice grain and straw. The mean $\mathrm{S}$ uptake by rice grain increased from 4.22 to 4.76 and $4.82 \mathrm{~kg} \mathrm{ha}^{-1}$ due to FYM and BGS application respectively. Such observations were also recorded by Sinha and Sakal (1993b) ${ }^{[15]}$ on groundnut crop in calcareous soil of north Bihar and by Singh et al. (1992) [13] for lentil crop on alluvial soils of Varanasi.

\section{Available sulphur status in post-harvest soil}

Maximum increase in available-S $\left(50.4 \mathrm{mg} \mathrm{kg}^{-1}\right)$ was noted at $120 \mathrm{~kg} \mathrm{~S} \mathrm{ha}^{-1}$ level and ranged from 8.1 to $43.6 \mathrm{mg} \mathrm{kg}^{-1}$ due to
S application without organic manures and from 19.7 to 57.2 $\mathrm{mg} \mathrm{kg}{ }^{-1}$ in organic manure treated plot after harvest of rice crop in mustard- rice sequence (Table 11). The increase in available sulphur status after harvest of rice crop is due to the fact that uptake of sulphur by mustard and rice was much lower as compared to the amount of sulphur applied hence, supporting the findings of Islam et al. (1997) ${ }^{\text {[5] in rice- }}$ mustard cropping system. The effect of organic manure was apparent after harvest of rice crop as available sulphur status was increased significantly from 24.2 to 32.9 and $37.9 \mathrm{mg} \mathrm{kg}^{-}$ ${ }^{1}$ in FYM and BGS treated plot, respectively. The interaction of organic manure and S-levels was found positive and significant, which showed the superiority of BGS over FYM at all levels of $\mathrm{S}$ application.

Table 10: Residual effect of sulphur application alone or along with organic manure on sulphur uptake $\left(\mathrm{kg} \mathrm{ha}^{-1}\right)$ by rice

\begin{tabular}{|c|c|c|c|c|c|c|c|c|c|c|c|c|}
\hline \multirow{3}{*}{$\mid \begin{array}{c}\text { Sulphur } \\
\text { levels } \\
\left(\mathrm{kg} \mathrm{ha}^{-1}\right)\end{array}$} & \multicolumn{4}{|c|}{ S uptake by rice grain } & \multicolumn{4}{|c|}{ S uptake by rice straw } & \multicolumn{4}{|c|}{ Total S uptake by rice } \\
\hline & \multicolumn{4}{|c|}{ Organic manures } & \multicolumn{4}{|c|}{ Organic manures } & \multicolumn{4}{|c|}{ Organic manures } \\
\hline & Control & FYM & BGS & Mean & Control & FYM & BGS & Mean & Control & FYM & BGS & Mean \\
\hline 0 & 2.92 & 3.49 & 4.43 & 3.61 & 6.48 & 6.70 & 9.09 & 7.42 & 9.40 & 10.19 & 13.52 & 11.04 \\
\hline 20 & 3.19 & 3.87 & 4.49 & 3.85 & 7.48 & 8.63 & 11.80 & 9.30 & 10.68 & 12.50 & 16.29 & 13.16 \\
\hline 40 & 3.82 & 4.32 & 4.69 & 4.28 & 8.97 & 10.55 & 12.15 & 10.56 & 12.79 & 14.87 & 16.84 & 14.83 \\
\hline 60 & 4.78 & 5.34 & 4.74 & 4.95 & 9.74 & 11.22 & 12.81 & 11.26 & 14.52 & 16.56 & 17.56 & 16.21 \\
\hline 80 & 4.80 & 5.25 & 5.15 & 5.07 & 9.84 & 12.32 & 14.01 & 12.06 & 14.64 & 17.58 & 19.16 & 17.13 \\
\hline 100 & 4.88 & 5.64 & 5.19 & 5.24 & 11.95 & 13.35 & 15.61 & 13.64 & 16.84 & 18.99 & 20.80 & 17.88 \\
\hline 120 & 5.15 & 5.40 & 5.04 & 5.20 & 12.78 & 14.38 & 16.68 & 14.61 & 17.92 & 19.78 & 21.72 & 19.81 \\
\hline Mean & 4.22 & 4.76 & 4.82 & - & 9.61 & 11.02 & 13.16 & - & 13.83 & 15.78 & 17.98 & - \\
\hline \multicolumn{3}{|c|}{ Sources } & \multicolumn{2}{|c|}{ S.Em \pm} & \multicolumn{2}{|l|}{$\mathrm{CD}(\mathrm{P}=0.05)$} & S.Em \pm & \multicolumn{2}{|c|}{$\mathrm{CD}(\mathrm{P}=0.05)$} & \multicolumn{3}{|c|}{ S.Em $\pm \mathrm{CD}(\mathrm{P}=0.05)$} \\
\hline \multicolumn{3}{|c|}{ Organic manures } & \multicolumn{2}{|l|}{0.10} & \multicolumn{2}{|l|}{0.28} & 0.30 & & 0.85 & 0.30 & & 0.86 \\
\hline \multicolumn{3}{|c|}{ S levels } & \multicolumn{2}{|l|}{0.15} & \multicolumn{2}{|l|}{0.43} & 0.45 & & 1.30 & 0.46 & & 1.32 \\
\hline \multicolumn{2}{|c|}{ Interaction } & & 0.26 & & \multicolumn{2}{|l|}{-} & 0.79 & & - & 0.80 & & - \\
\hline
\end{tabular}


Table 11: Available sulphur $\left(\mathrm{mg} \mathrm{kg}^{-1}\right)$ in post- harvest surface soil $(0-15 \mathrm{~cm}$ depth $)$ of rice

\begin{tabular}{|c|c|c|c|c|}
\hline \multirow{2}{*}{$\begin{array}{c}\text { Sulphur } \\
\text { Levels }\left(\mathrm{kg} \mathrm{ha}^{-1}\right)\end{array}$} & \multicolumn{4}{|c|}{ Organic manures } \\
\hline & Control & FYM & BGS & Mean \\
\hline 0 & 8.1 & 19.7 & 20.8 & 16.2 \\
\hline 20 & 15.0 & 21.4 & 23.9 & 20.1 \\
\hline 40 & 17.8 & 24.1 & 29.2 & 23.7 \\
\hline 60 & 20.1 & 31.7 & 36.1 & 29.3 \\
\hline 80 & 29.5 & 40.8 & 48.7 & 39.7 \\
\hline 100 & 35.6 & 42.2 & 49.2 & 42.3 \\
\hline 120 & 43.6 & 50.3 & 57.2 & 50.4 \\
\hline Mean & 24.2 & 32.9 & 37.9 & - \\
\hline \multicolumn{2}{|c|}{ Sources } & \multicolumn{2}{|c|}{ S. $E_{m} \pm$} & $\mathrm{CD}(\mathrm{P}=0.05)$ \\
\hline \multicolumn{2}{|c|}{ Organic manures } & \multicolumn{2}{|l|}{0.4} & 1.0 \\
\hline \multicolumn{2}{|c|}{ S levels } & \multicolumn{2}{|l|}{0.6} & 1.6 \\
\hline \multicolumn{2}{|c|}{ Interactions } & 1.0 & & 2.8 \\
\hline
\end{tabular}

\section{Conclusions}

It was revealed in this study that sulphur application significantly increased the yield of mustard, S concentration and its uptake by mustard (seed + straw) and rice (grain+ straw) as well as available $\mathrm{S}$ content in post-harvest soil samples after mustard and after rice crop. The beneficial effect of organic manure was evident in enhancing the seed and stover/straw production, S-concentration in seed, Suptake (seed + straw) by mustard and rice and available-S content in post-harvest soil samples. Mean available sulphur in post-harvest soil after mustard and rice increased significantly from 25.7 to $86.5 \mathrm{mg} \mathrm{kg}^{-1}$ and 16.2 to $50.4 \mathrm{mg}$ $\mathrm{kg}^{-1}$ respectively with increasing $\mathrm{S}$ levels, i.e. $\mathrm{S}$ application at higher rates left sufficient available-S in soil after one complete cycle of rotation. It was observed that $S$ application has definite residual effect on succeeding crop rice as evinced by significant increase in yield, S-content and its uptake by subsequent rice crop as well as available sulphur content in post-harvest soil. The contribution of organic manure was apparent in increasing the grain yield, S-content in grain, straw, total S-uptake (grain + straw) and available $\mathrm{S}$ content in post-harvest samples of mustard and rice crop. Biogas slurry proved superior to FYM in improving the above plant and soil characters. Thus, the residual effect of higher level of $\mathrm{S}$ along with BGS proved more effective with respect to $\mathrm{S}$ nutrition to rice. Still after two crops, the influence of BGS was found superior over FYM in enhancing available-S status of soil.

\section{References}

1. Ankineedu G, Rao JV, Reddy BN. Advances in fertilizer management for rainfed oilseeds. Fertil. News. 1983; 28(9):76-90.

2. Aulakh MS, Pasricha NS. Sulphur fertilization of oilseed for yield and quality. In Sulphur in Indian Agriculture. Fert. Assoc. India. The sulphur Institute, Washington, D.C., 1988, 1-14.

3. Aulakh MS, Pasricha NS, Dev G. Response of different crops to sulphur fertilization in Punjab. Fertil. News. 1977; 22(9):32-36.

4. Chesmine L, Yien CH. Turbidimetric determination of available sulphates. Soil Science Society of America Proceedings. 1951; 15:149-151.

5. Islam MR, Riasat TM, Jahiruddin M. Direct and residual effects of $\mathrm{S}, \mathrm{Zn}$ and $\mathrm{B}$ on yield and nutrient uptake in a rice-mustard cropping system. J. Indian soc. sc. 1997; 45:126-129.
6. Jackson ML. Soil Chemical Analysis. Prentice Hall of India, New Delhi, 1978.

7. Kour S, Arora S, Jalali VK, Bali AS, Gupta M. Direct and residual effect of sulphur fertilization on yield, uptake and use efficiency in Indian mustard and succeeding rice crop. Journal of Plant Nutrition. 2014; 37(14):2291-2301.

8. Kour S, Jalali VK, Arora S. Vertical distribution of forms of sulphur in some sub-tropical zone soils of Jammu region. Environment and Ecology. 2007; 25:708-712.

9. Lindsay WL, Norvell WA. Development of a DTPA soil test for zinc, iron, manganese and copper. Soil Sci. Soc. Am. Proc. 1978; 42:421-428.

10. Mishra SK. Effect of sulphur and zinc on yield, uptake of nutrients and quality of mustard. Annals of Plant and Soil Research. 2001; 3:206-213.

11. Sakal R, Singh AP, Sinha RB, Bhogal NS. Twenty-five years of research on micro-and secondary nutrients in soils and crops of Bihar. Research bulletin. Deptt. of Soil Sci., R.A.U., Pusa, 1996.

12. Singh S, Singh AP, Singh B. Direct and residual effect of pyrites on yield, sulphur content and quality characters of groundnut and mustard. J. Indian Soc. Soil Sci. 1991; 39:328-331.

13. Singh S, Singh AP, Singh B. Direct and residual effect of pyrites on yield, protein content and $S$ uptake by blackgram and lentil in Entisol. J. Indian Soc. Soil Sci. 1992; 40:584-585.

14. Sinha RB, Sakal. Effect of pyrite and organic manures on sulphur nutrition of crops in calcareous soil. Direct effect on lentil. J. Indian Soc. Soil Sci. 1993a; 41:312-315.

15. Sinha RB, Sakal R. Effect of pyrite and organic manures on sulphur nutrition of crops - Il. Residual effect on groundnut and wheat. J. Indian soc. Soil sci. 1993b; 41:316-320.

16. Tabatabai MA. Sulphur. In Methods of Soil Analysis. Part 2. Chemical andMicrobiological Properties. Agronomy Monograph No. 9 (C.A Black, Ed.), 2nd ed. pp. 501-538. Soil Science Society of America, Madison. (c.f. Soil Biol. Biochem. 1982, 1994; 26:1507-1514.

17. Tandon HLS. Fertilizer Recommendations for Oilseed crops - A Guidebook. FDCO, New Delhi, 1990, 46.

18. Tandon HLS. Sulphur Research and Agricultural Production in India. 3rd edn. The Sulphur Institute, Washington, D.C, 1991.

19. Tripathi HC, Singh RS, Mishra VK. Effect of S and Zn nutrition on yield and quality of chickpea (Cicer arietinum L.). J. Indian Soc. Soil Sci. 1997; 45:123-126.

20. Walkley A, Black CA. An Examination for wet acid method for determination soil organic matter and proposed modification of the chromic acid titration method. Soil Science. 1934; 37:29-38. 